\title{
Past, Present, and Future of Jesuit Studies: Historiographical Thoughts
}

\author{
John W. O'Malley, S.J. \\ Georgetown University \\ jwog@georgetown.edu
}

\begin{abstract}
The author traces the history of Jesuit studies, portrays the current status of the field, and reflects on its future developments. The article reproduces the third annual Feore Family Lecture on Jesuit Studies, delivered by John W. O'Malley on October 3, 2017, at Boston College. On that occasion, the Institute for Advanced Jesuit Studies awarded O'Malley with the George E. Ganss, S.J., Award in Jesuit Studies, to recognize his significant scholarly contributions to the field.
\end{abstract}

\section{Keywords}

Jesuit studies - George Ganss - John Padberg - The First Jesuits - Institute of Jesuit Sources - Weston Jesuit School of Theology - Jesuit Institute at Boston College Institute for Advanced Jesuit Studies

I cannot tell you how honored I am to receive the Ganss award. I have received other marks of recognition, but none of them is as meaningful to me as this one. The award brings together institutions and persons that have touched my life in a variety of ways, none more important than how they converge here at Boston College at this moment.

I will therefore enter the subject of my lecture autobiographically. The name George Ganss is professionally important and personally dear to me. In 1954, he published his Saint Ignatius' Idea of a Jesuit University, in which he outlined the discrepancy he saw between the original sources and the reality he experienced in the present. The book was a landmark, the first step in North America in what we can call the renaissance of Jesuit studies that we are experiencing

(C) JOHN W. O'MALLEY, 2018 | DOI:10.1163/22141332-00504001

This is an open access article distributed under the terms of the prevailing CC-BY-NC license at the time of publication. 
today. Even more important and of more lasting import was his translation into English of the Jesuit Constitutions in 1970, the first version of that document in any modern language. He had meanwhile become head of the fledgling Institute of Jesuit Sources, which is now flourishing here at Boston College.

In the latter years of the 196os, in the wake of Vatican Council II and of the reawakening of Jesuit studies especially in France but by then in a limited way also in the United States, the Jesuit provincials founded the Seminar in the Spirituality of Jesuits and asked George to head it. The Seminar now operates out of Boston College.

When I was a doctoral student at Harvard University, I had an interest in doing my dissertation on a Jesuit subject, but a casual conversation in Widener Library with a member of the Boston College faculty dissuaded me from doing so. He told me that I was too close to the subject and should first write on something else. That sounded like good advice, and I followed it. I went on to write my dissertation on an Augustinian friar, and then I wrote on Dominicans, Franciscans, and preachers in the Sistine Chapel during the Renaissance.

In 1979, however, George Ganss invited me to join the Seminar, and I accepted, thinking this might be my chance finally to write something about the Jesuits. While I was on the Seminar, Pope John Paul II intervened in the Society and appointed Father Paolo Dezza as his delegate to govern the Society for an unspecified time.

The event sent waves of shock and fear through the Society. The intervention seemed to relate to the Jesuits' fourth vow, often incorrectly and deplorably described as a vow of loyalty to the pope. The members of the Seminar, led by Ganss, insisted that, in view of the intervention, the Seminar simply had to publish something on the vow. I objected. The subject was too obscure, too little researched, and too complicated for us to address. The scandalous fact is that at that time even Jesuits were not altogether clear about what the vow they pronounced entailed.

At a certain moment in our discussion in the Seminar, I must have closed my eyes because when I looked around the room everybody was pointing at me. Against my better judgment, I agreed to see what I could find and I went to work. I think I came up with the right answer, and we published it. That was my first venture into Jesuit studies, thanks to George Ganss and the Seminar. In the course of my research on the vow, I began to read the works of Jerónimo Nadal, Saint Ignatius's best interpreter, and I got excited. In retrospect, I see that the time had finally arrived when I was about to take the plunge into Jesuit studies.

That brings me to John Padberg, quite properly the first person to receive the Ganss award and George Ganss's successor as both the chair of the Seminar and as the director of the Institute of Jesuit Sources-a close and cherished friend for over fifty years. Our friendship began the first moment we met, when 
he, a beginning doctoral candidate in the History Department at Harvard, persuaded me that Harvard was the place for me to do my own doctorate. I followed John's advice, which ran contrary to my original intention of studying at the University of Bonn with Hubert Jedin, the great historian of the Council of Trent. Although it would have been wonderful to study under Jedin, choosing Harvard was one of the best decisions I have ever made. The Harvard History Department turned out to be the perfect place for me. My friendship with John Padberg deepened when I soon joined him in the doctoral program at Harvard.

In 1975, John became president of the Weston Jesuit School of Theology in Cambridge, which is now at Boston College under its new name of the School of Theology and Ministry. As soon as John became president, he tried to persuade me to join the faculty. I resisted, but after about two years, I finally agreed to try it. It was another of the best decisions I have ever made. Without it, I probably would not have written The First Jesuits—or, if I had written it, it would have been a different and a poorer book.

The years 1990 and 1991 marked, respectively, the $450^{\text {th }}$ anniversary of the founding of the Society of Jesus in 1540 and the birth of Saint Ignatius in 1491. I wanted to write something to honor the occasion, and, still enthusiastic about what I had been discovering in Nadal, decided to write a book about him for the occasion. I soon saw, however, that that was not what was needed. History textbooks and even distinguished historians described the Society as founded to fight the Reformation and reform the Catholic Church. I wanted to write a book to counter such myths and misunderstandings, and I went to work on what turned out to be The First Jesuits.

By then I had written a fair amount on the ministry of preaching in the Renaissance, which sensitized me to teaching at a school of ministry, which is what Weston was and what the School of Theology and Ministry at Boston College is today. The experience of Weston further sensitized me to what I found in the sources about the centrality of ministry in the early Jesuits. The first half of The First Jesuits is about ministry.

The book culminates in the chapter on schooling, which within a few years of the founding of the Society became not only the Society's most important ministry but also the ministry that transformed the Society of Jesus itself. It made proficiency in secular subjects a defining characteristic of the order. It thereby imbued the mission of the Society with civic and cultural dimensions that were new for a religious order. It, therefore, also imbued Jesuit spirituality with civic and cultural dimensions, even though writers on that subject rarely reckon with those dimensions.

Thus, the Jesuits were worldly, as their enemies so astutely perceived but without understanding the spiritual vision that sublimated the worldliness. In any case, the schools imbued the Society with a remarkably distinctive 
identity, strikingly different from that of any other religious order up to that time. The Society of Jesus would in time have become barely distinguishable from the medieval mendicants.

Harvard University Press was located just a few blocks from Weston. Dr. Lindsay Waters, one of the editors at the press, had contacted me about a book Harvard was considering translating. In the course of one of our conversations, I asked him if he might be interested in publishing my book on the Jesuits, and he gave me an enthusiastic response. I was already determined not to publish with a religious press because I wanted the secular public to read the book and thus help break Jesuit studies out of the Jesuit and Catholic ghetto in which they still largely languished. The First Jesuits appeared in 1993.

Meanwhile John Padberg, now as director of the Institute of Jesuit Sources in Saint Louis continued the publishing of important works on Jesuit history, which included volumes of the decrees of the Jesuits' general congregations that he in masterly fashion edited. In the United States, which had lagged behind Spain and France, Jesuit studies were heating up.

After the publication of The First Jesuits, I began to receive letters especially from younger scholars; many of them still graduate students, asking me about aspects of Jesuit history. It occurred to me that they had no way of networking with one another and that many of them had never met a Jesuit. Would it not be good to bring them together for a weekend so that they might meet and share ideas? This seemed like a good idea. I realized, however, that some were starving graduate students and others just beginning their professional careers. We would have to fund the meeting, but a modest sum would do it.

With that, I proposed the idea to Father Michael Buckley of the Boston College Theology Department. I approached Michael because he was also director of the Jesuit Institute at Boston College, which I knew had funds disposable for such a project. I proposal the project to him, underscoring how modest its scope and how small the amount that would be needed.

Michael sat back, looked at me, and then exclaimed, "O, John, for heaven's sake, THINK BIG. We can raise all the money that is needed." THINK BIG! In that moment, the game had completely changed. I enlisted three other scholars to form with me a planning team-Gauvin Alexander Bailey, an art historian; Steven J. Harris, a historian of science (neither of whom were Catholics); and a musicologist, T. Frank Kennedy, a Jesuit member of the Boston College faculty. The four of us worked beautifully together as for two years we planned the conference. From the beginning, Frank was determined to hold the conference at Boston College, which is what happened. The project got bigger and bigger, ever more international and multidisciplinary. Our budget 
therefore also got bigger and bigger. Although it was very definitely not easy to raise the money, eventually we succeeded.

In 1987, in anticipation of the great anniversaries in 1990-91, I had thought of trying to organize a conference to observe them, but I could not think of a sufficient number of qualified scholars to do so. This was partly due to my ignorance of the field but more fundamentally to the state of Jesuit studies worldwide, which was just beginning to awake from its slumber.

However, as we planned our conference ten years later, we were surprised to find a more than sufficient number of scholars, junior and senior, in a wide diversity of fields, eager and qualified to attend. The conference, entitled "The Jesuits: Cultures, Sciences, and the Arts, 1540-1773," opened at Boston College for four days in the spring of 1997, with about fifty scholars from around the world invited to attend, a number supplemented by others who came on their own.

The conference was a resounding success, as was the second a few years later, and as were the large volumes we published of the more important papers from each of the conferences. It is difficult to exaggerate how important these conferences and volumes were on an international and multidisciplinary level. They burst whatever was still parochial and confessional about Jesuit studies and they displayed to the entire world how rich in resources for almost any aspect of human endeavor the history of the Society of Jesus was. These two conferences held at Boston College were not simply important conferences among other important conferences. They were turning points in Jesuit studies and powerful catalysts in promoting them further-on an international, multidisciplinary, and non-confessional basis.

Now we need to step back from the story of what happened with Jesuit studies in the United States during the final decade of the twentieth century. That story is only a chapter, though an extremely important chapter, in the middle of a much larger story. Let me now try to place the chapter in its larger context.

The leading figures of the first generation of Jesuits were all university trained, and they knew the importance of good record keeping and of the impact of past decisions on present reality. From the very first decade of the order, therefore, the Jesuits showed a sophisticated concern for keeping full and orderly archives. They also knew that history was the story of how they got to be what they were. They therefore from the earliest years showed a lively interest in the history of the order, as through the centuries did subsequent generations. In the introduction to the volume of studies from our first conference at Boston College, I gave an account and an analysis of how those traditions developed up to the time of the conference. This afternoon, I will simply point out a few of the more salient features of the traditions. 
During the Renaissance, humanists emphasized basing history on original sources, and took the first steps in elaborating principles of textual criticism. They, at the same time, believed with their literary heroes in Greek and Roman antiquity that history was "philosophy teaching by example," that is, history was the rhetorical side of moral philosophy because it presented examples of virtuous behavior for imitation and of corrupt behavior for shunning. Jesuit historians like their secular counterparts in the Renaissance adopted both the critical and moralizing aspects of this historiographical development. The result was histories that were, on the one hand, factually correct but, on the other, a form of social hagiography.

Historiography changed radically in the nineteenth century. Historians no longer professed to practice a branch of moral philosophy but strove to present, warts and all, simply "what really happened" — in the often quoted words of Leopold von Ranke, wie es eigentlich gewesen. The change banished edification as a legitimate aim of historical studies. It, at the same, time promoted a new enthusiasm for the production of critical editions of important texts, which culminated in the Weimar edition of the works of Martin Luther, undertaken by German Lutheran scholars in 1883, the four-hundredth anniversary of Luther's death.

The Jesuits did not want the Lutherans to outdo them. A small group of Spanish Jesuits in Madrid, well trained in the newly honed methods of critical editing, set about publishing a critical edition of the full correspondence of Saint Ignatius and some related documents. The first volume rolled off the press in 1894. Thus began the Monumenta Historica Societatis Iesu, which developed into a magnificent series of critical editions of documents from the early history of the Society that now numbers over 150 volumes. It is difficult once again to exaggerate the importance of having such documents so readily available to the researcher. They made for an incalculably more thorough, searching, and balanced history.

The actual writing of the Society's history continued to be almost exclusively the task of the Jesuits themselves. Despite the merits of much the Jesuit historians produced, they found it difficult altogether to shake the apologetic and hagiographic tradition of historical writing. They tended, moreover, to know the history of the Society of Jesus and that history alone, which imbued much they wrote with a stale in-house quality that lacked a sophisticated sense of how the Jesuits fit in the cultures in which they found themselves. Their histories were heavy on information, light on analysis. Other scholars simply were not interested in Jesuit history. The history of the Jesuits was, after all, an aspect of the history of the dull and retrograde Counter-Reformation. Why bother with it? 
The Second Vatican Council helped Jesuits break out of their traditional framework by projecting a more expansive view of the church, which suggested a more expansive view of the traditions of the Society of Jesus. Meanwhile, a few historians who were not Jesuits and not Catholics began to discover that Jesuit history was not as dull as they had thought, and they began to produce solid studies of it. This was the state of affairs at the time I wrote The First Jesuits.

Where are we now? Twelve years ago, in 2005, I published in America magazine an article entitled "Jesuit History: A New Hot Topic." If I were to write that article today, I would entitle it "Jesuit Studies: The Hottest Game in Town." To change metaphors, we are riding the crest of a tidal wave. Books and articles about the Jesuits are pouring off the presses almost around the world at a stunningly rapid pace. I myself feel overwhelmed by it. The good news is that the quality of the tidal wave is extraordinarily high, the variety of disciplines represented wide, and the methods employed up to date and diverse.

Whereas fifty years ago Jesuits produced ninety-five per cent of the historical scholarship on the Society of Jesus, today lay scholars, most of whom are not Catholics, produce that percentage or more. This imbalance is bad for the Society of Jesus, and it is not good for the discipline. The Society loses touch with its lived traditions. The discipline suffers from losing the insight provided by insider historians. Nonetheless, we need to exult and rejoice at the lively, sophisticated, and extraordinarily copious condition of Jesuit studies today.

What about the future? How long will the tidal wave maintain its momentum? Scholars know that there is a time and tide in scholarship. A topic is hot for a decade and then cools almost into oblivion. In the 1980s, my hero, Erasmus, was a hot topic, but the heat wave soon passed. Others have suffered the same fate. But not all. The American Civil War continues to fascinate both scholars and a wider readership. What about the Jesuits?

Who is to say? Certainly, not I. Four features of Jesuit studies suggest, however, that it might continue to be of interest for a long time to come. The first is its great chronological expanse, now close to five hundred years. That means lots to look at. The second is its geographical expanse: virtually every country and every culture in the world at one time or another. The third is its disciplinary richness, which obviously includes theology, philosophy, education, and practices of piety. Yet, it also includes cartography, astronomy, hydraulic engineering, theater, physics, anthropology, emblem composition, lexicography, architecture, fortifications, the designing and executing of week-long civic spectacles, the silversmith's craft, hotel management, painting, city planning, archivistica, the history and theory of dance, poetry, the theory and practice of 
rhetoric, theatrical entrepreneurship, hospice management, music, accounting, organization theory and practice.

The last reason, but certainly not the least is the overflowing abundance and the high quality of the sources that survive. The Jesuits were compulsive and intelligent record keepers. They also were obliged to write frequent and frank letters describing the situations in which they found themselves and to give a frank and honest account of both successes and failures. In terms of sheer quantity, the records they left behind could fill warehouses. Although the central archives are in Rome, other large and important deposits of documents rest in peace in archives and attics almost worldwide.

In any case, there are certainly interesting topics that beg for exploration. I think, for instance, of Jesuit pharmacies, whose specialties were natural remedies such as quinine, sent from the Jesuit missions. Their history remains unaddressed. How about some detailed studies on what happened to Jesuit properties at the time of the suppression? Although we are finally getting helpful studies of the suppression itself, we still lack an analysis of how Father General Lorenzo Ricci dealt with the series of crises that culminated in the suppression and of how leading Jesuits evaluated his passivity in the face of the threat. We know a lot about Jesuit missionaries to Latin America, to Japan and China, but much less about India, and even less about Africa.

Aside from a slender volume by Louis Châtellier published several decades ago, we have virtually no studies of the Jesuits' Marian Congregations, those associations of lay persons who in some ways acted as the Jesuits' equivalent of a third order. The Marian Congregations were an extremely important instrument of Jesuit ministry. They were also highly influential civic and cultural institutions that undertook a variety of functions. The congregation attached to the Jesuit church of San Fedele in Milan, for instance, sponsored the premiere of Vivaldi's last oratorio.

As far as I know, we do not have a single study of a Jesuit novitiate at any time in the Society's history. Nor do we have a history of such an important house of study for Jesuits in training that was Woodstock College in Maryland. The story of its founding, the role of European expatriates on its faculty, its transfer to New York City, and the trauma of its closure is well worth the telling for the light it throws on American culture, Catholic and secular.

The mention of Woodstock raises a truly big issue. Up to this time, the best scholarship has focused on the so-called Old Society, that is, the Society before the suppression in 1773 and restoration in 1814. No doubt, in many ways the older history is more polychrome and culturally rich, but recent studies have shown how interesting and enlightening the history of the New Society can be. 
I think especially of the splendid work of Gerald McKevitt on Italian missionaries to the Pacific Northwest, and of the new volume brilliantly conceived and edited by Stephen Schloesser, Crossing and Dwellings, about the Jesuits in the American Midwest. I cannot omit mention of Giacomo Martina's book on the Italian Jesuits of the New Society, nor of Klaus Schatz's monumental volumes on the German Jesuits for the same period.

The list of subjects begging for research could go on forever. Let me, therefore, change focus and suggest two approaches to Jesuit history that need pursuing. The first is an interdisciplinary approach. Today Jesuit studies is spectacularly multi-disciplinary, but rare are studies in which scholars from several disciplines try to integrate among themselves their findings on a given subject, thus providing an integral picture of it. Next April, Fairfield University will sponsor an exhibition of art objects from the church of the Gesù in Rome. The catalog for the exhibition promises to be such an interdisciplinary study, even though art history is, quite understandably, the dominant discipline represented.

The second is a diachronic approach. Last year, I published a little book entitled The Jesuits and the Popes. It is a sketch of the relationship between the Jesuits and the popes from Ignatius to the present; the first time such a diachronic study has ever been done on what seems to be an obvious, interesting, and crucially important topic. I would like to claim credit for the idea, but in fact, a French publisher requested the book of me.

Not only the French think in diachronic terms. For some years now, Princeton University Press has published a series of monographs entitled "Biographies of Spiritual Classics," that is, studies of the origin and subsequent interpretation of important books on spirituality. I, at one point, agreed to write for Princeton such a biography of the Spiritual Exercises, but then begged off because of other commitments. In my lifetime, the Spiritual Exercises has undergone significant shifts in interpretation and practice. Would it not be enlightening, for instance, to have a study of how much attention was paid to the "Rules for Thinking with the Church" at any given period of history? The first directories to the Exercises suggest that at least for the first fifty years after the publication of the Exercises in 1548, the "Rules" received very little attention.

On an even larger scale, how about a diachronic study of the interpretations of Saint Ignatius himself? The saint described himself as a pilgrim, but Nadal, his earliest interpreter proposed him as the David standing up to Luther, the giant Goliath, and initiated the image of Ignatius as the prototypical saint of a militant Counter-Reformation. The earliest paintings of Ignatius depict him in a simple black cassock, but by the early seventeenth century artists such as 
Rubens began to depict him vested in a chasuble standing by an altar, which was part of the Jesuit campaign to have him canonized.

In the nineteenth century during the bitter controversies over papal infallibility, Ignatius emerged as the ultramontane saint par excellence, that is, a saint almost defined by his zeal in defending and promoting papal prerogatives. In the past thirty years, he has emerged as the author of "Ignatian spirituality." There are certainly excellent grounds for such an attribution, but the naming and identification of the reality known as Ignatian spirituality is new, which means that the spirituality is itself somehow new.

That concludes my all too swift and cursory romp through the past, present, and future of Jesuit studies. So what? Here is the so-what. At the moment Jesuit studies is indeed the hottest game in town. The Institute for Advanced Jesuit Studies is helping make it so. The future of Jesuit studies looks bright and exciting, and the Institute is poised to play the single most important part in it. I am not exaggerating when I say that the Institute has made Boston College the single most important center of Jesuit studies in the world. It has achieved this standing by means of its continuation of the Institute of Jesuit Sources. It has achieved it by means of its publication of the Journal of Jesuit Studies and its publication of monographs in its new series entitled Jesuit Studies: Modernity through the Prism of Jesuit History, both of which Robert Maryks founded and continues so ably and energetically to supervise. It has done this by means of its other undertakings. There is nothing like the Institute anywhere else.

I congratulate the staff of the Institute and especially its director, Father Casey Beaumier. I congratulate and thank Father William Leahy, president of Boston College, for the support he has shown the Institute from the time of its inception, and I once again express my gratitude for the honor bestowed upon me this afternoon. As I have explained, the Ganss Award is precious to me and brings back the sweetest of memories. Thank you. 